\title{
Managing Approach the Workload Balance Over Workstations at Stage Process Engineering Part- Making in Multi-Product Production
}

\author{
Sergey Grigoriev ${ }^{1}$, Vitaliy Dolgov ${ }^{1,2}$, Alexey Podkidyshev ${ }^{2}$, and Petr Nikishechkin ${ }^{1,2, ~ *}$ \\ ${ }^{1}$ MSUT «STANKIN», Moscow, Russia \\ ${ }^{2}$ LLC "Digital Systems Factory", Moscow, Russia
}

\begin{abstract}
This paper shows the features of workflow distribution on workplaces on the technical process preparation stage of parts production and the operational and calendar planning stage. Also, the problem of workflow distribution on workplaces was formulated and the mechanism of its occurrence was described. An algorithm for managing the distribution of the volume of work by jobs at the stage of technological preparation of production was developed.
\end{abstract}

\section{Introduction}

Ensuring a uniform workflow on workplaces in the multi-nomenclature machine-building production in modern conditions is becoming increasingly relevant. Fluctuations in the production program lead it to a change in the workflow and uneven loading of workplaces which increases the production cycle time [1-4].

In the conditions of the modern machine-building products market, we can talk about periodic fluctuations in the production program, therefore, the availability of mechanism of balancing the workplaces workload is one of the requirements that determine the competitiveness of multi-nomenclature machine-building enterprises [2,5-8].

\section{Two-level balancing of the workplace's workload}

Nowadays, the main mechanism for managing the production capacity utilization balancing during the implementation of the established program is the development of production schedules. The efficiency of balancing production capacities is determined not only by the production planning algorithms used.

The following factors and their combinations have a significant impact on workload balancing [5,9-12]:

- product nomenclature,

- production program,

- production time,

\footnotetext{
* Corresponding author: npa@digitalfabrika.ru
} 
- technological processes,

- specification of workplaces.

The scheme of developing a production schedule is shown in Figure 1.

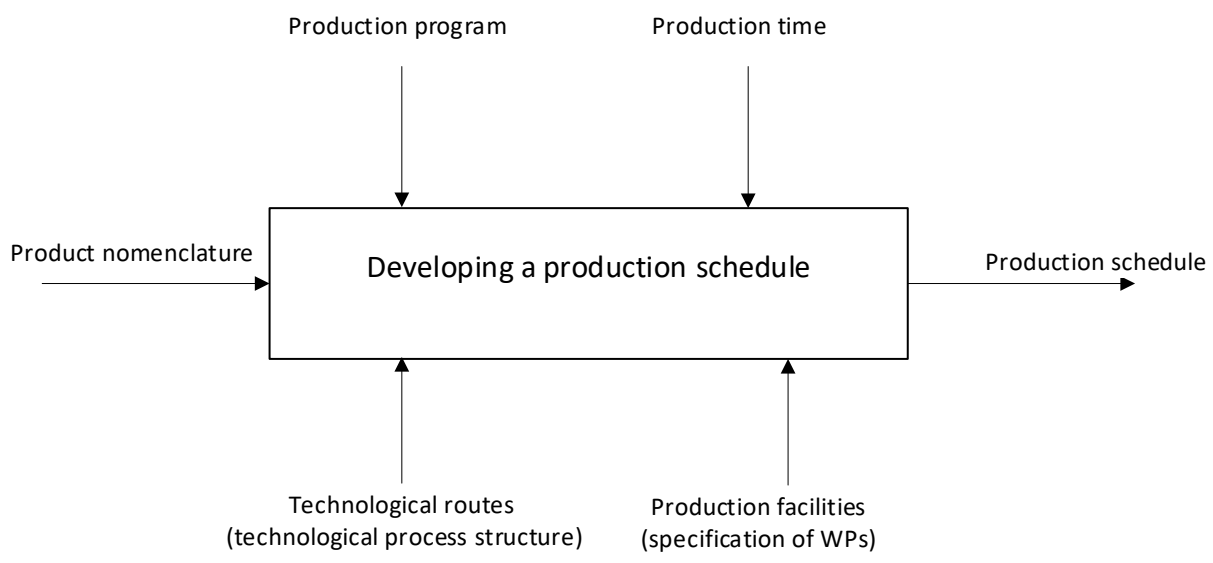

Fig. 1. The scheme of development of the production schedule.

The development of technological processes and the specification definition of workplaces is carried out during a new enterprise design or during the technical re-equipment of an existing enterprise to ensure the release of a given nomenclature and program [2].

Technological processes determine the work composition (operations) and the distribution of the work flow to workplaces. Thus, technological processes form the basic balancing of the workload of workplaces for the implementation of a given program, within which the development of production schedules is carried out [13-16].

The basic balancing mechanism of the workplaces workload on the example of a milling processing shop area showed below.

Shop area working hours: 2 shifts.

Workplaces on the shop area:

WP 1 - the vertical milling CNC machine (axes number of 3)

WP 2 - the vertical milling CNC machine (axes number of 3 )

WP 3 - the vertical milling CNC machine (axes number of $3+1$ )

WP 4 a vertical milling CNC machine (axes number of $3+1$ )

WP 5 a vertical milling CNC machine (axes number of $3+2$ )

The workload of workplaces during the execution of the current production program is presented in tables 1,2 .

Table 1. Annual workload of workplace 1 (WP1) when processing the nomenclature of parts assigned to it.

\begin{tabular}{|c|c|c|c|c|}
\hline \multicolumn{5}{|c|}{ WP 1: Vertical milling CNC machine (number of axes 3) } \\
\hline \multicolumn{5}{|c|}{$\begin{array}{c}\text { Nominal fund of equipment operating time: } 3900 \text { hours. } \\
\text { Accepted equipment load factor: 0.8 }\end{array}$} \\
\hline Part name & $\begin{array}{c}\text { Operation } \\
\text { number }\end{array}$ & $\begin{array}{c}\text { Operation } \\
\text { duration, min }\end{array}$ & $\begin{array}{c}\text { Products } \\
\text { number for a } \\
\text { given period }\end{array}$ & $\begin{array}{c}\text { Machine processing } \\
\text { capacity of the } \\
\text { program, h }\end{array}$ \\
\hline Bracket & 020 & 21,2 & 200 & 70,7 \\
\hline Frame & 045 & 9,8 & 300 & 49 \\
\hline Plate & 075 & 8 & 220 & 29,3 \\
\hline$\ldots$ & $\ldots$ & $\ldots$ & $\ldots$ & $\ldots$ \\
\hline Total & & & & \\
\hline
\end{tabular}


Table 2. Loading of workplaces of the milling machine section during the implementation of the current production program.

\begin{tabular}{|c|c|c|}
\hline Workplace name & $\begin{array}{c}\text { Machine processing } \\
\text { capacity of the program, } h\end{array}$ & $\begin{array}{l}\text { Utilization } \\
\text { factor, } \mathrm{Ku}\end{array}$ \\
\hline $\begin{array}{l}\text { PM1 - the vertical milling CNC machine model } 1 \\
\text { (axes number of } 3 \text { ) }\end{array}$ & 3152 & 0,8 \\
\hline $\begin{array}{l}\text { PM2 - the vertical milling CNC machine model } 2 \\
\text { (axes number of } 3 \text { ) }\end{array}$ & 3113 & 0,79 \\
\hline $\begin{array}{l}\text { PM3 - the vertical milling CNC machine model } 3 \\
\text { (axes number of } 3+1 \text { ) }\end{array}$ & 3270 & 0,83 \\
\hline $\begin{array}{l}\text { PM4 - the vertical milling CNC machine model } 4 \\
\text { (axes number of } 3+1)\end{array}$ & 3034 & 0,77 \\
\hline $\begin{array}{l}\text { PM5 - the vertical milling CNC machine model } 5 \\
\text { (axes number of } 3+2)\end{array}$ & 3113 & 0,79 \\
\hline Average value for a group of machines & - & 0,8 \\
\hline
\end{tabular}

The values of the workplace utilization factor $(\mathrm{Ku})$ shown in Table 1 indicate a uniform average annual load of workplaces. The basic balancing of the WP load was carried out for a given production program during the technological preparation of production $[4,7,17-20]$.

When the production program is changed, the load balancing of workplaces is disrupted. The planned workload of workplaces when changing the production program is presented in tables 3,4 .

Table 3. Annual workload of workplace 1 (WP1) during the implementation of the planned production program.

\begin{tabular}{|c|c|c|c|c|}
\hline \multicolumn{5}{|c|}{$\begin{array}{c}\text { Nominal fund of equipment operation time: } 3900 \\
\text { Accepted equipment load factor: 0.8 }\end{array}$} \\
\hline \multirow{2}{*}{ Part name } & $\begin{array}{c}\text { Operation } \\
\text { number }\end{array}$ & $\begin{array}{c}\text { Operation } \\
\text { duration, min }\end{array}$ & $\begin{array}{c}\text { Products number } \\
\text { for a given period }\end{array}$ & $\begin{array}{c}\text { Machine } \\
\text { processing } \\
\text { capacity of the } \\
\text { program, } \mathbf{~}\end{array}$ \\
\hline Bracket & 020 & 21,2 & 350 & 123,7 \\
\hline Frame & 045 & 9,8 & 150 & 24,2 \\
\hline Plate & 075 & 8 & 110 & 14,7 \\
\hline$\ldots$ & $\ldots$ & $\ldots$ & $\ldots$ & $\ldots$ \\
\hline Total & & & & 4728 \\
\hline
\end{tabular}

Table 4. Loading of workplaces of the milling machine section during the implementation of the planned production program.

\begin{tabular}{|c|c|c|}
\hline Workplace name & $\begin{array}{l}\text { Machine processing capacity } \\
\text { of the program, } h\end{array}$ & $\begin{array}{l}\text { Utilization } \\
\text { factor, } \mathrm{Ku}\end{array}$ \\
\hline $\begin{array}{l}\text { WP } 1 \text { - the vertical milling CNC machine model } 1 \\
\text { (axes number of } 3 \text { ) }\end{array}$ & 4728 & 1,2 \\
\hline $\begin{array}{l}\text { WP } 2 \text { - the vertical milling CNC machine model } 2 \\
\text { (axes number of } 3 \text { ) }\end{array}$ & 3152 & 0,8 \\
\hline $\begin{array}{l}\text { WP } 3 \text { - the vertical milling CNC machine model } 3 \\
\text { (axes number of } 3+1 \text { ) }\end{array}$ & 2758 & 0,7 \\
\hline $\begin{array}{c}\text { WP } 4 \text { - the vertical milling CNC machine model } 4 \\
\text { (axes number of } 3+1 \text { ) }\end{array}$ & 3743 & 0,95 \\
\hline $\begin{array}{c}\text { WP } 5 \text { - the vertical milling CNC machine model } 5 \\
\text { (axes number of } 3+2 \text { ) }\end{array}$ & 2364 & 0,6 \\
\hline Average value for a group of machines & - & 0,8 \\
\hline
\end{tabular}


Figure 2 shows the values of the load factors of the workplaces of the milling machine section during the implementation of the current and planned production program.

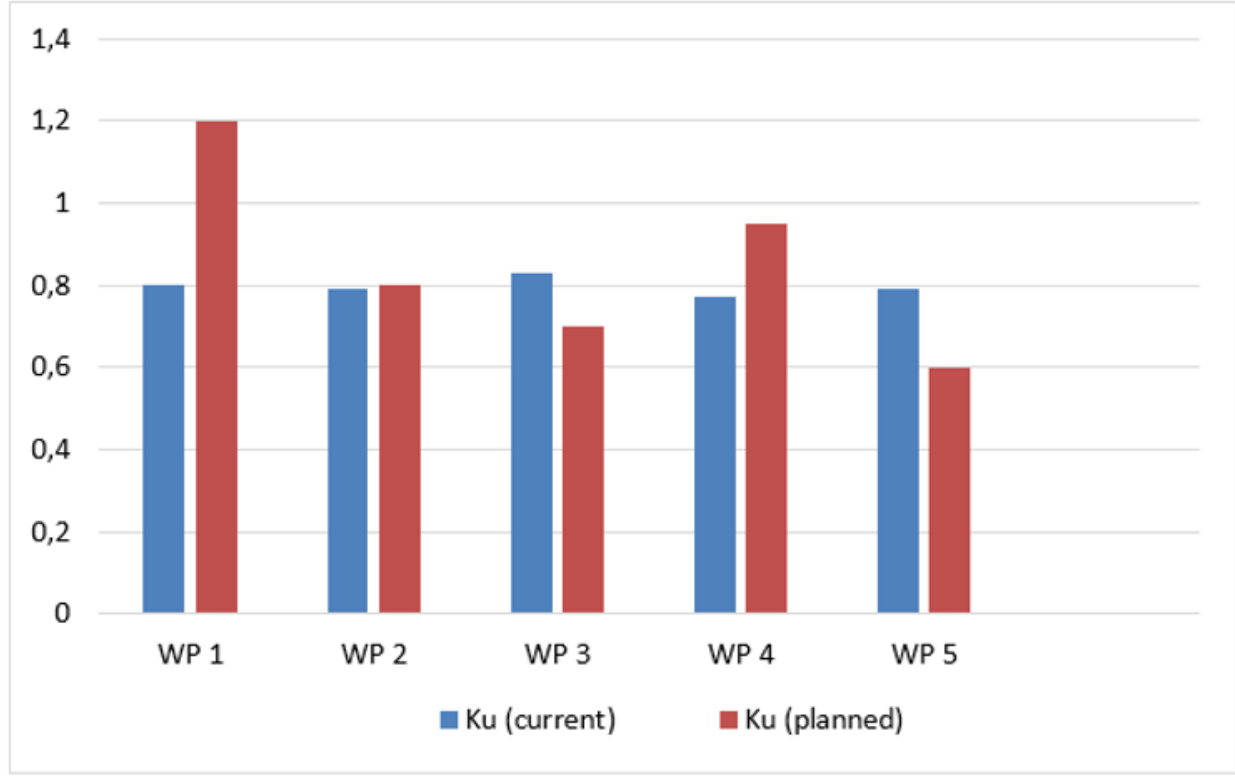

Fig. 2. Factors of workplaces loading of the milling machine section.

The average value of the load factor of the milling machine section has not changed. However, the analysis of the values of the load factor of workplaces during the implementation of the planned production program showed the presence of overloaded and underloaded workplaces [21-26].

The overloaded workplaces (WP1 and WP4) will not be able to perform the amount of work assigned to them.

In accordance with the above, it can be concluded that with the normative value of the load factor of the milling machine section, the amount of work assigned to the shop area cannot be performed.

It is impossible to solve the problem of performing a given amount of work according to the planned production program in this situation by optimizing the production schedule without increasing the working time fund.

To ensure that the specified amount of work is performed according to the planned production program, it is necessary to transfer part of the work from WP1 and WP2 to WP3 and WP5. At the same time, the technological possibility of performing the transferred work at these workplaces should be taken into account [16,27].

The production schedule solves the tasks of operational balancing of production capacities in a short period of time within the framework of the distribution of the work flow established by technological processes.

Thus, there are two levels of production capacities balancing to be distinguished (figure $3)$. 


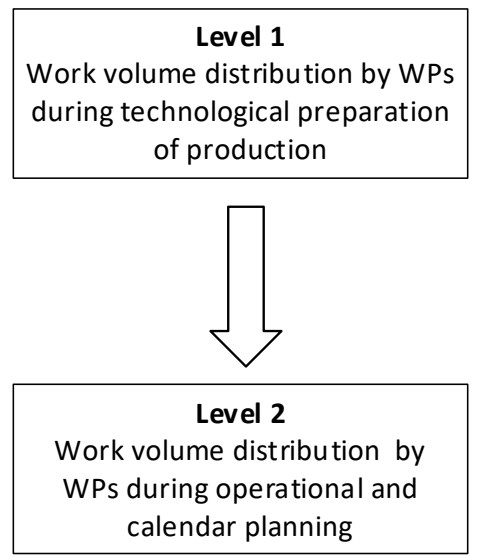

Fig. 3. Production capacity balancing levels.

A feature of multi-nomenclature machine-building enterprises is the periodic change of the product range and the program of their release at their operation stage. Such changes lead it to a violation of the basic production capacity utilization balancing [28-32].

The modern practice of production planning does not monitor changes in the basic balancing of production capacities and it tries to solve the balancing problem by production planning methods, i.e. by operational balancing [18,27,33].

The main requirement taken into account when developing technological routes is to ensure the specified parameters of product quality. At the same time, the specification of available workplaces is used as restrictions. The tasks of ensuring load balancing of workplaces are not considered. This practice is due to the lack of necessary mechanisms.

One of the solutions for operational balancing is the use of alternative technological routes without changing the basic balancing. It is worth noting that alternative technological routes for the production of one nomenclature item are based on a single structure of the technological process, which determines organizational solutions for distributing the workflow to workplaces, thus, it determines the concentration or differentiation of technological transitions in technological operations [10,34-37].

This approach increases the possibilities of operational balancing, but it has also limitations due to the use of a unified technological process structure installed during basic balancing.

Thus, balancing the utilization of production capacities is a complex process that covers the levels of strategic and operational management and can be considered as a process of managing the distribution of the workflow across workplaces. The management of the distribution of the workflow includes various mechanisms: the formation of organizational and technological solutions, changing the composition of the WP, changing the scheme of cooperation, changing the working time fund, changing the system of maintenance and repairs to improve the reliability of the WP, etc [8,38].

In this paper, it is considered as a process of managing the distribution of the workflow to workplaces in discrete machine-building production based on the organizational formation and technological solutions.

Taking into account the above, an algorithm for controlling the distribution of the work flow to workplaces in the manufacture of parts in discrete machine-building production was proposed. This algorithm scheme is shown in Figure 4. 


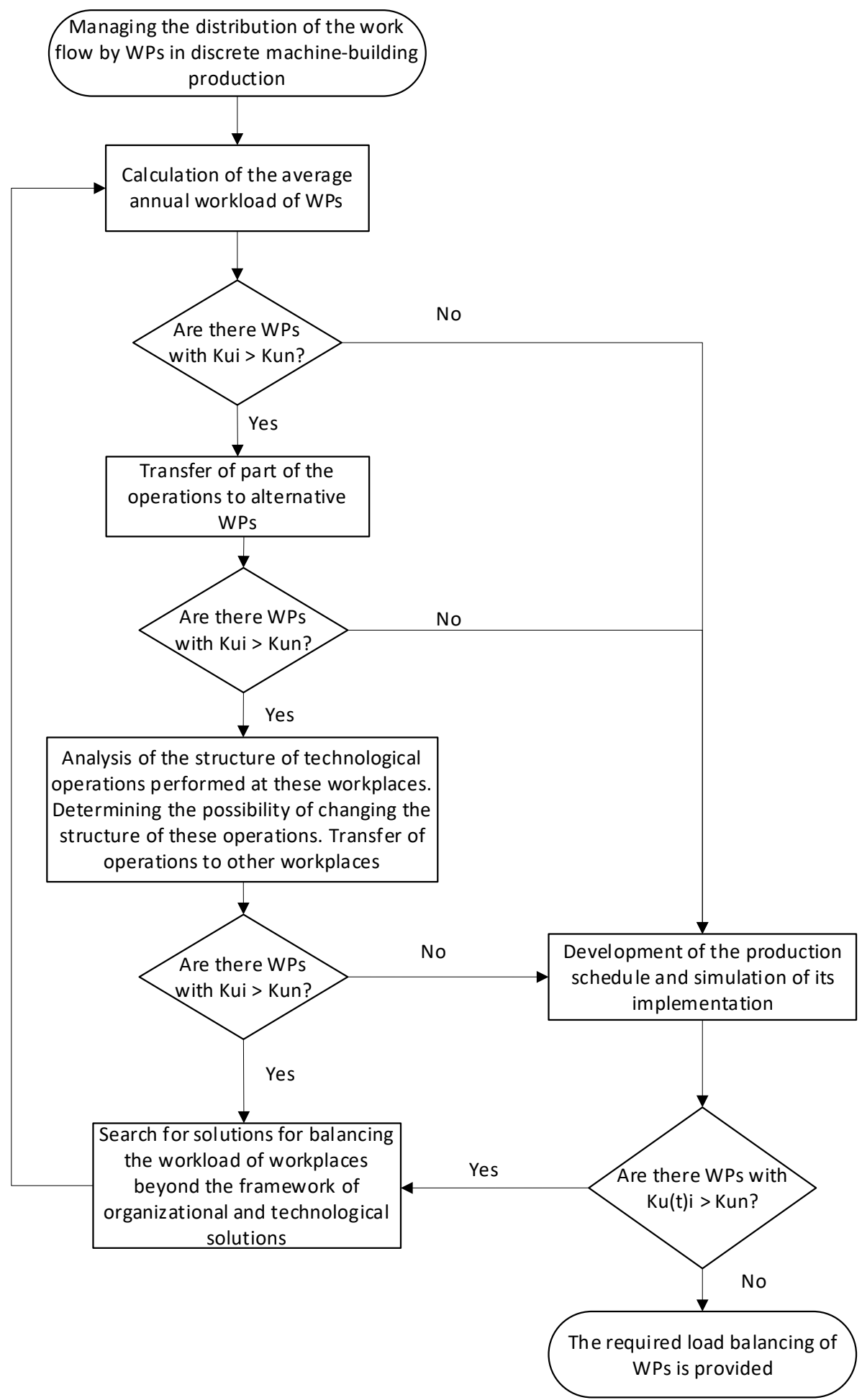

Figure 4. Algorithm for distributing the flow of work to workplaces in discrete machine-building production by changing technological processes. 
The algorithm is based on the step-by-step formation of balancing solutions.

At the first level of balancing, it identifies WPs which have average annual load factor (Kui) is greater than the standard value (Kun).

Changing the technological process's structure is a time-consuming process and, in some cases, requires changing the technological equipment.

The most preferable solution is to distribute the workflow without changing the structure of the technological process operations. This can be achieved by creating alternative workplaces, increasing the productivity of operations by changing technological modes, using high-performance tools, etc [14,19].

If it is impossible to perform balancing due to the use of alternative workplaces, organizational and technological solutions based on changing the operations structure of technological processes are being worked out.

We believe that at the second level of balancing it is impossible to form a production schedule for workplaces that have Kui $>$ Kun.

Therefore, if it is impossible to balance the workload of workplaces by changing the structure of operations, solutions should be sought in other directions indicated above [39].

At the second level of balancing, a production schedule is formed and a simulation of the behavior of the technological system is carried out when this schedule is fulfilled.

The research object at this level is the peak workplaces workload in the time period $t \mathrm{Ku}$ (t)i), caused by the overlap of the workflow, the unavailability of the WP for technical reasons, the influence of random factors, etc.

\section{Conclusions}

The article considers the features of the distribution of the volume of work on the WP at the stage of the engineering process preparation and the stage of operational calendar planning (development of the production schedule).

It is shown that the capabilities of production planning systems are limited by organizational and technological solutions formed at the engineering process preparation stage $[20,40]$.

The analysis of ways of balancing the WP load at the engineering process preparation stage is carried out and groups of organizational and technological solutions that affect the distribution of the volume of work on the WP are identified.

This research shows the algorithm for managing the distribution of the volume of work on the WP at the engineering process preparation stage

Verification of balancing solutions based on the calculation of performance indicators based on modeling the execution of a given production program.

This work is funded by the state assignment of the Ministry of Science and Higher Education of the Russian Federation, project No. 0707-2020-0025.

\section{References}

1. Y. Ouazene, F. Yalaoui, H. Chehade, A. Yalaoui, International Journal of Computational Intelligence Systems 7, 58-67 (2014)

2. S. Grigoriev, V. Dolgov, P. Umnov, N. Fokin, O. Proshkina, MATEC Web of Conferences 329, 03076 (2020)

3. V. Dolgov, P. Nikishechkin, V. Arkhangelskii, P. Umnov, A. Podkidyshev, EPJ Web of Conferences 248, 04015 (2021) 
4. B. Raghavendra, A. Murthy, M. Jayaram, International Journal of Engineering Science and Technology 3, 1 (2011)

5. V. Dolgov, V. Arkhangelski, P. Nikishechkin, 2020 International Multi-Conference on Industrial Engineering and Modern Technologies, 1-6, (2020)

6. S. Grigoriev, G. Martinov, Proc. CIRP 14, 517-522 (2014)

7. M. Yildirim, E. Duman, K. Krishna, International Journal of Operations Research 4, 42-49 (2007)

8. V. Gorelov et al., Kontrol. Diagnostika 11, 53-59 (2007)

9. S. Grigoriev, G. Martinov, Proc. CIRP 41, 858-863 (2016)

10. K. Bouzakis, G. Skordaris, G. Maliaris, E. Bouzakis, S. Makrimallakis, G. Katirtzoglou, S. Gerardis, J. Balk. Tribol. Assoc. 18, 106 (2012)

11. S. Grigoriev, M. Kozochkin, F. Sabirov, A. Kutin, Proc. CIRP 1, 599-604 (2012)

12. V. Dolgov, P. Nikishechkin, A. Leonov, S. Ivashin, N. Dolgov, EPJ Web of Conferences 248, 04014 (2021)

13. B. Raghavendra, A. Murthy, International Journal of Engineering Science and Technology 2,5 (2010)

14. V. I. Zavgorodnii, M. P. Kozochkin, A. R. Maslov, F. S. Sabirov, Russian Engineering Research 30, 939 (2010)

15. A. Kutin, V. Dolgov, A. Kabanov, et al. IOP Conference Series-Materials Science and Engineering, 448, 012008, (2018)

16. S. Grigoriev, V. Gurin, M. Volosova, N. Cherkasova, Materwiss. Werksttech. 44, 790$796(2013)$

17. S. Grigoriev, V. Dolgov, A. Leonov, IOP Conference Series: Materials Science and Engineering, 971, 032093 (2020)

18. N. Kochinev, F. Sabirov, Meas. Tech. 52, 621 (2009)

19. S. Grigoriev, V. Teleshevskii, Meas. Tech. 54, 744-749 (2011)

20. E. Nakhapetyan et al., STIN 5, 2-9 (2006)

21. C. Berger, H. Scheerer, J. Ellermeier, Materialwiss. Werkstofftech 5, 41 (2010)

22. S. Mehrdad, A. Nassehi, ST Newman, Robotics and Computer Integrated Manufacturing, 29,79-87 (2013)

23. N. G. De Mattos De Mesquita, J. E. F. De Oliveira, A. Q. Ferraz, Adv. Mater. Res. 223, 554 (2011)

24. J. Fleischer, A. Broos, M. Schopp, J. Wieser, H. Hennrich, CIRP Journal of Manufacturing Science and Technology 1, 179 (2009)

25. A. Schubert, A. Nestler, R. Funke, Materialwiss. Werkstofftech 41, 795 (2010)

26. M. Siddhpura, R. Paurobally, International Journal of Machine Tools and Manufacture 61 (2012)

27. S. Grigoriev, V. Dolgov, P. Nikishechkin, N. Dolgov, IOP Conference Series: Materials Science and Engineering, 971, 032094, (2020)

28. A. Balykov, Yu. Serdobintsev, L. Listunov, Glass Ceram 64, 99 (2007)

29. A. Schubert, A. Nestler, S. Pinternagel, H. Zeidler, Materialwiss. Werkstofftech. 42 , 658 (2011)

30. S. Grigoriev, V. Sinopalnikov, M. Tereshin, V. Gurin, Meas. Tech. 55, 555-558 (2012) 
31. Xiong-bo M, Zhen-yu H, Yong-zhang W, Hong-ya F, Chinese Journal of Aeronautics 20, 272-281 (2007)

32. G. Campos, J. Hardwick, M. Hardwick, International Journal of Computer Integrated Manufacturing 22, 112-128 (2009)

33. L. Pengfei, G. Tao, W. Jianping, L. Hongzhao, Robotics and Computer-Integrated Manufacturing 26, 720-724 (2010)

34. C. Chih-Wei, K. Chun-Pao, International Journal of Machine Tools and Manufacture, 47, 452-461 (2007)

35. H. Ding, YC. Shin, International Journal of Machine Tools and Manufacture, 50, 106114 (2010)

36. S. Grigoriev, G. Martinov, Procedia CIRP, 1, 238-243 (2012)

37. M. Minhat, V. Vyatkin, X. Xu, S. Wong, Z. Al-Bayaa, Robotics and ComputerIntegrated Manufacturing, 25, 560-569 (2009)

38. ST. Newman, A. Nassehi, XW. Xu, RSUJ. Rosso, L. Wang, Y. Yusof, et al., Robotics and Computer-Integrated Manufacturing, 24, 699-708 (2008)

39. M. Rauch, R. Laguionie, JY. Hascoet, SH. Suh, Robotics and Computer Integrated Manufacturing, 28, 375-384 (2012)

40. M. Mori, M. Fujishima, M. Komatsu, B. Zhao, Y. Liu. CIRP Annals - Manufacturing Technology, 57, 433-436 (2008) 